\title{
Exploring the role of primary learners' parents in modular distance learning
}

Lopez, Julie Ann $\bowtie$

Laguna College of Business and Arts, Philippines (annj.lopez2314@gmail.com)

Revised: 4 August 2021

DOI: $10.5861 /$ ijrse.2021.a050



ISSN: 2243-7703

Accepted: 5 August 2021

OPEN ACCESS

\section{Abstract}

This study explored the lived experience of primary learners' parents and their role in Modular Distance Learning in the Division of Calamba City. The research design used was qualitative with phenomenology as an approach with the use of purposeful sampling. The respondents of the study included fifteen (15) Primary Learner Parents in selected public schools in the East District of Calamba City. Using thematic analysis, the study generated ten (10) superordinate themes which were Varied Preparations for Modular Distance Learning, Learning Facilitator, Different Techniques as Parent-teacher, Time Management and Perseverance, Subsiding Focus on Learning, Forms of Encouragement, Challenges on Modular Distance Learning, Acceptance and Positive Outlook, Dealing with New Normal Education, and Additional Responsibilities. Under the first theme, it explored different preparations of parents in modular distance learning. For the second theme, all the parents had similar perceptions on their role for their children's education which was to guide and facilitate learning at home. As for the third theme, the parents described their different approaches in guiding their child at home. In the fourth theme, the parents described their ways in managing their time under the modular distance learning. For the fifth and sixth themes, parents revealed common problems occurred and their ways on encouraging their child in modular learning. For the seventh and eight themes, parents revealed the challenges they encountered during the transition to modular learning, and their coping mechanisms to changes in education. As for the ninth theme, parents described the factors that were helpful to them. Lastly, the parents revealed that this modular distance learning gave them additional responsibilities. As an output of the study, the compilation of ways of adapting to modular distance learning from inspirational testimonies of parents about their roles was proposed to inspire, motivate, and help other parents to overcome challenges. Through this booklet, this will help parents to adjust to changes in education that will benefit their children. With this, parent's undying support is a great help to these changes.

Keywords: role, primary learners, parents, modular distance learning 


\title{
Exploring the role of primary learners' parents in modular distance learning
}

\section{Introduction}

\author{
"Education is key for generations of Filipinos to become full-fledged, productive members of the \\ society.” -Sonny M. Angara
}

Education shows the value of hard work and helps human growth and development. It is everyone's path to success and achieving one's goal especially for the youth. It serves as their training ground to provide them knowledge and skills to prepare them succeed in life. Thus, a better world was formed to live in through knowing and upholding rights and rules. The formation of a child's character begins at home. As a result, every family member aims to make the home a wholesome and harmonious environment, as the home's atmosphere and conditions have a significant impact on the child's growth. In addition, education is the key to progress in life, finding better work, and eventually succeeds. In the Philippines, education is always the priority of parents for their children. It is the greatest investment for people to have more chances of finding a career that they enjoy. This is why the Department of Education (DepEd) is finding ways and different approaches to continue quality education despite the pandemic that we experience right now. In this light, the continuity of learning in the midst of pandemic lies in the full support from the parents, schools and the community.

In the Philippines, the COVID-19 crisis has affected about 27 million learners, 1 million teachers and non-teaching staff, as well as the families of learners. Due to this pandemic, most of the students and parents are having second thoughts on their children's education. With this, DepEd Secretary Briones (2020) stated that with or without the conduct of face-to-face instruction, opening of classes for School Year 2020-2021 will still continue. DepEd is addressing the challenges in the basic education for the school year 2020-2021 through its Basic Education Learning Continuity Plan (BE-LCP) under DepEd Order No. 012, s. 2020. However, since the situation is new in the education system in the Philippines, parents, teachers, and the community, everyone faces new challenges that affect the education system in the country. With that, the researcher is prompted to conduct this study in order to describe the lived experience of parents in modular distance learning. This is to explore the parents' struggles, concerns, and problems what they encountered in their life in conducting modular as an approach to learning. The researcher claimed that the role and responsibility of parents in this time is important, since parents are the teachers, guidance and facilitator to their children's learning experiences. Therefore, the researcher explored good and bad experiences of parents as they perform their role as teacher or facilitator of modular distance learning.

\subsection{Conceptual Framework}

This study is anchored on concepts of parent involvement which serve as a basis for the study on the lived experiences of parents in the modular distance learning. Parental involvement in the child's education can take place in or outside of school, with the intention of improving children's learning is anchored to Epstein Parent Involvement Model (2019). This widely accepted framework mentioned one factor which is parenting that refers to helping families build and strengthen parenting skills and set up home environments that support children as learners. Some practice examples of this type are suggestions for home conditions that serve to improve learning, parental education activities and family support programs.

In addition, learning at home was also mentioned in this model that is about providing information and ideas to families about how to help their children at home with homework and other curriculum-related activities, behavioral expectations, making good decisions, and planning. This factor involves information on homework policies and how to supervise children, family reading activities at school. In this study, the Epstein Parent Involvement is anchored to the lived experiences of primary learner parents using Modular Approach in learning 
who face challenging situations in guiding and teaching their children at home. Since everyone shifted to the new normal education, parent's role and encouragement are vital to the learning experiences and academic success of their child. Now that each is on this situation, parent's role is close to the teacher's role because they will be the one to guide and to teach their child in modular approach.

Figure1. Research Paradigm

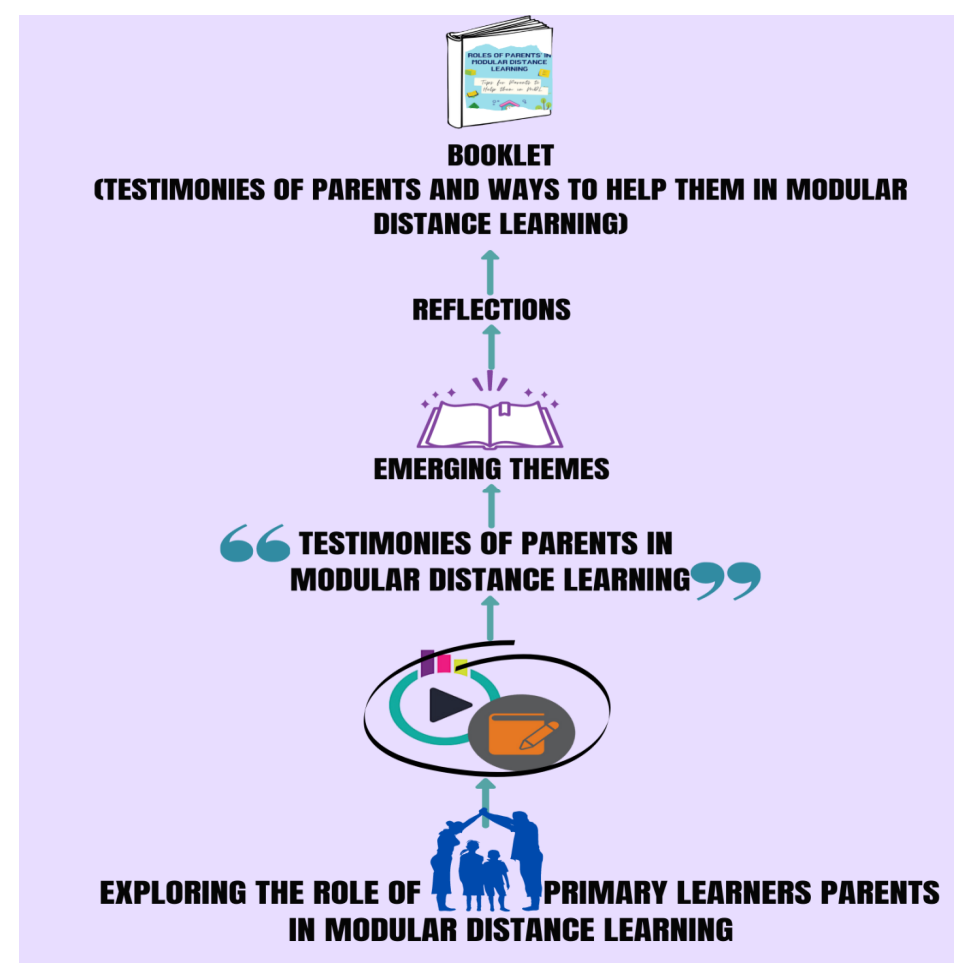

\subsection{Central Question}

The main thrust of this phenomenological inquiry was to determine the lived experience of primary learners' parents in modular distance learning. Specifically, this sought to answer the following central and corollary questions:

What is the essence of the lived experience of primary learners' parents as they partake their role in modular distance learning?

\subsection{Corollary Questions}

$>\quad$ How do the selected primary learners' parents describe their experiences as they perform their role in modular distance learning?

$>\quad$ What themes emerged from the testimonies of primary learners' parents as they perform their role in modular distance learning?

$>$ Based on the consolidated results and reflections, what booklet can be proposed to heighten parental role on modular distance learning?

\subsection{Scope and Delimitations}

The clarity of focus, this research undertaking is guided by the following scope and delimitations:

The researcher utilized qualitative research design with phenomenology as an approach to understand the lived experience of parents as they performed their role in modular distance learning. The study was participated by 15 parents of learners enrolled at the primary grade level in the Real Elementary School under the Schools Division of Calamba City. Each question was directed to the point and the size was chosen with the idea of 
getting a higher degree of certainty. The line of questioning during the interview limits to the purpose of extracting themes that arose from the study.

Additionally, the study determined the challenges faced by the parents in modular distance learning and sought for recommended actions to address those challenges. The findings of the study were used only as basis for the development of a booklet that can be proposed to heighten parental role in Modular distance Learning.

\section{Review of Related Literature and Studies}

The related information gathered and included in this chapter was used to analyze, verify, and strengthen the data gathered and themes emerged throughout the process of the study, which further helped the researcher to come up with a strong conclusion. The related information gathered and included in this chapter was used to analyze, verify, and strengthen the data gathered and themes that emerged throughout the process of the study, which further helped the researcher to come up with a strong conclusion, all in line with what has already been known through previous studies.

Based on the articles of DepEd (2020) and UNESCO (2020), different platforms for distance learning are applicable for learners with different situations. They shared that these platforms are uited for learners in the continuity of learning. In addition, Basilaia and Kvavadze (2020) and Pacheco (2020) shared that learning institution needs to study how successful online learning is in providing quality education and revisiting the curriculum represents a particular opportunity to promote a different path forward. Moreover, Bernardo (2020) and Magsambol (2020) explained the same understanding that learning through printed modules emerged as the most preferred distance learning method of parents with children who are enrolled in the academic year of 2020-2021. This is also in consideration of the learners in rural areas where internet is not accessible for online learning. Specifically, based on the articles of Ancheta (2020) and Kamalludeen (2020), the efficacy of the monitoring and evaluation process is necessary. The evaluation must focus on the results of students' performance to measure the achievement of the learning outcomes. Meanwhile, Obana (2020), Bendijo (2020), and Basilaia and Kvavadze (2020) emphasized that the same perceptions about the new normal education w which is very new to everyone. They also pointed out that there are different learning modalities should be used to continue their children's education in the pandemic; and these learning modalities should be fit to every learner's situation.

In line with this, Magsambol (2020) discussed that there are printed modules to be given to learners who have no access to internet connection and gadgets especially in public schools. Furthermore, Bandijo (2020), Dr. Servito (2020), and Bayocot (2020) provided same perception about involvement of parents. They stated that the parents' role in the child's learning in this pandemic is vital because they need to establish connection and guide their child's learning process using the modules. They also shared that parents are the home facilitators who will guide the learning of their child. For Pollard (2020), for parents to become involve in their child's education is providing a rich learning environment in their homes. With this, Keith (2020) added that other parent involvement activities are communicating with the teacher and school, discussing school activities with their child, and monitoring and supervising their child's out of school activities.

Overall, the studies and literature mentioned above showed the same view point of this inquiry on how the live experiences of primary learners' parents on modular approach during this new normal education which focuses on their roles, challenges encountered, and how they overcome it. These literatures also showed the view on modular distance learning that helped the researcher to anchor the blogs, studies and theory of the expert for this study.

\section{Methodology}

Research Design - This study utilized the qualitative research with phenomenology analysis as approach. Phenomenology Analysis that brings added dimensions to the study of human experiences through qualitative

38 Consortia Academia Publishing (A partner of Network of Professional Researchers and Educators) 
research. This study utilized the qualitative research with Phenomenology as an approach. According to Creswell (2014), "phenomenological study describes the common meaning for several individuals of their lived experiences of a concept or a phenomenon". He added that research questions at the onset, as well as data collection procedures or protocols may change along the way depending on what ongoing data collection and inductive analysis reveal. In addition, he also stated that one of the key elements of collecting data in qualitative approach is to observe the participants during their engagement in the activities.

Instrument - The researcher utilized semi-structured interview in her study. Also, she conducted an interview to gather data through online meeting with the participants. The researcher used 10 guide questions which were used as interview questions for 15 parents from Grade 1 to Grade 3 Level. The interview was started in April 2020 and was completed in May 2020. She utilized the following interview questions to the participants.

Participants of the Study - Phenomenology is concerned with the lived experiences of people involved in the study. The fundamental goal of the approach is to arrive at a description of the nature of the particular phenomenon (Creswell, 2013). The participants of this study were the ten (15) primary learners' parents from Grade 1 to Grade 3 in the four schools from the East District of Division of Calamba City Laguna and the following schools are Bucal Elementary School, Jose Rizal Memorial Elementary School, Parian Elementary School and Real Elementary School. They were the joint contributors and investigators to the findings of this study.

Table A

Participants of the Study

\begin{tabular}{llll}
\hline Participant & Gender & Age & \multicolumn{1}{c}{ Status/ Nature of Work } \\
\hline Parent 1 & Female & 28 & Housewife/ 4 Children \\
Parent 2 & Female & 30 & Housewife/ 1 Child \\
Parent 3 & Female & 26 & Housewife/ 1 Children \\
Parent 4 & Female & 31 & Housewife/ 5 Children \\
Parent 5 & Female & 35 & Government Employee/ 3 Children \\
Parent 6 & Female & 29 & Housewife/ 3Children \\
Parent 7 & Female & 28 & Housewife/ 3 Children \\
Parent 8 & Female & 27 & Business/ 1 Child \\
Parent 9 & Female & 30 & Business/ 3Children \\
Parent 10 & Female & 30 & Private Company/ 4 Children \\
Parent 11 & Female & 29 & Housewife/ 2 Children \\
Parent 12 & Female & 32 & Housewife/ 3 Children \\
Parent 13 & Female & 28 & Housewife/ 2 Children \\
Parent 14 & Female & 33 & Government Employee/ 3 Children \\
Parent 15 & Male & 38 & Government Employee/ Single Parent \\
\hline
\end{tabular}

Table A shows the 15 participants that were interviewed for this study including their age, gender, and the family status or nature of work of the parents.

Data-Gathering Procedure - In the conduct of the study, standard operating procedure was applied to obtain the best possible result. This research study used standard operating procedure to obtain the best possible result. The interview questions were scrutinized and validated to obtain the essential data. The researcher asked for the consent of the Schools Division Superintendent in the Division of Calamba City. The permission letters were submitted to individual school administrator/s and teachers of the chosen schools. Then, researcher prepared letters for the chosen participants. The date and time of the holding of the interview via zoom. The letter also indicated that the participants' responses kept confidential. The researcher prepared recording gadgets, notes and guide questions before she conducted the interview. After the interview, the researcher encoded and transcribed the data in verbatim. Thereafter, the she approached the school official analyst who helped her in deriving the emerging themes.

Treatment of Qualitative Data - The researcher utilized thematic analysis as a means of analyzing the data 
collected from the responses of the participants. According to Caufield (2019), thematic analysis is a method of analyzing qualitative data. It is usually applied to a set of text; such as interview transcripts. The researcher closely examines the data to identify common themes such as topics, ideas and patterns of meaning that come up repeatedly.

After gathering all the data coming from an interview conducted, the researcher started the steps for the treatment of qualitative data using Interpretative Phenomenological Analysis (IPA) that aimed to offer insights into how a person in a given context makes sense of a given phenomenon. The researcher transcribed the interviews of the 15 primary learners' parents then afterwards, the researcher cited the relevant responses of the participants by themes. The emerging themes extracted from the similar responses per line of the verbatim transcription. The emerging themes were identified and extracted from the similar responses per line.

The last step involved an interpretation of data based on the results of the study regarding the lived experiences of primary learners' as they perform their role on modular distance learning. Observations and reflections were incorporated as the researcher described, analyzed and interpreted the lived experiences of the participants of the study.

\section{Results and discussion}

Interview Question 1. What are your preparations for your child's education in modular distance learning?

\section{Table 1}

Annotated exemplars on the varied preparations for modular distance learning

\begin{tabular}{cll}
\hline Participant & \multicolumn{1}{c}{ Responses } & \multicolumn{1}{c}{ Researcher's Observation } \\
\hline Parent 2 & "Una po ma'am yung kwarto po namin ginawa ko po na parang & Parent 2 entusiastically expressed \\
& classroom. Naglagay po ako ng mga alphabets po para mafeel niya na & and shared her feeling on her \\
& feeling niya na nasa school po siya kahit na nasa bahay po kame. Tapos po & preparations in modular distance \\
& bumili rin po ako poster yung pang school po ayun po mga ganun po." & learning. \\
Parent 8 & "Yung una po hinanda ko po muna yung mga bata, ipinaliwanag ko po & Parent 8 showed seriousness while \\
& muna sa kaniya na ganito po na hindi muna pwedeng pumasok sa school & answering the question on why \\
& kasi may pandemic po kailangan libro lang ang gagamitin nila. Ganun po & they need to learn at home. \\
& ipinaliwanag ko po muna sa kaniya na walang face-to-face class ngayon. & \\
& May mga tanong din po yung bata lalo na po yung kinder ko ma'am kasi & \\
& first time niya kasi talagang papasok po kaya sinabi ko na lang na mas & \\
& safe po pag nasa bahay kaya wala po munang face-to-face class ngayon." & \\
\hline
\end{tabular}

When asked about their preparations for their child's education in modular distance learning, Parent 2 and Parent 8 both expressed their feelings in their own way. For Parent 2, she was more enthusiastic on the preparations in modular distance learning. She shared her thoughts clearly on how she prepared a conducive learning environment for her child even at home. Meanwhile, Parent 8 shared her answer in seriousness. For her, explaining to her child about the situation first is her first step in preparation for modular distance learning so that her child will understand.

In line with Parent 2's testimony, Servito (2020) mentioned that one of the roles of parents is to provide conducive learning space for their child. This will allow their child to focus and motivated in answering the module. Parents can provide learning space for children through making them feel that learning at home is safe and fun as well. By having learning space at home that is much like in school, they may find modular distance learning a way in continuing learning at home. In addition, according to Pendly and Joseph (2020), a parent should talk about current events with their kids often. It is important to help them think through stories they hear about. Like

Lebaste (2020) pointed out that in distance learning approach, parents would have to play an active role in the learning process. They would be the one to facilitate and guide their children through the modular lessons that would be sent to students while doing remote learning. The testimonies of the parents on the preparation for 
Exploring the role of primary learners' parents in modular distance learning

modular distance learning were highlighted with the construction of a learning area, a mini-classroom perhaps, where their children feel the atmosphere of the school even at home.

Interview Question 2. As a parent, what is/are your role for your child's education in modular distance learning that has been helpful for your child?

\section{Table 2}

Annotated exemplars on the parents' duties on their child's learning

\begin{tabular}{|c|c|c|}
\hline Participant & Responses & Researcher's Observation \\
\hline Parent 4 & $\begin{array}{l}\text { "Ako po yung parang nagaguide sa bata para masagutan yung } \\
\text { sa modyul niya. Ako po yung nagiging facilitator niya. At dahil } \\
\text { grade } 3 \text { marunong na siyang magbasa, independent na siya so } \\
\text { siya na mismo yung gumagawa ng modyul niya chinecheck ko na } \\
\text { lang after ng activity." }\end{array}$ & $\begin{array}{l}\text { Parent } 4 \text { expressed her positive feeling on } \\
\text { her role on her child's education. }\end{array}$ \\
\hline Parent 11 & $\begin{array}{l}\text { "Ahh yung mga tungkulin ko ay yung tungkulin ko ahm iexplaine } \\
\text { sa kanila o ipaliwanag yung mga meaning ng mga ano yung ng } \\
\text { lesson and to see to it that na hindi lang basta basta binabasa } \\
\text { kundi naiintindihan din nila. And iguide ko rin sila sa mga } \\
\text { activities na hayaan ko sila talaga mismo yung nag aanswer } \\
\text { nun." }\end{array}$ & $\begin{array}{l}\text { Parent } 11 \text { greatly highlighted on how to } \\
\text { make sure that her child understands the } \\
\text { lesson. She shared it with a pleasant look } \\
\text { on her face. }\end{array}$ \\
\hline
\end{tabular}

When asked about their role for their child's education in modular distance learning that has been helpful for the child, Parent 4 expressed her positive feeling on her role on her child's education. Meanwhile, Parent 11 greatly highlighted on how to make sure that her child understands the lesson. She shared it with a pleasant look on her face. Both highlighted their role in their child's education in modular distance learning as a facilitator. They both gave a well thought answer on their vital role to provide learning at home.

In relation to this, FlipScience (2020) explained that since education is no longer held within the school, parents serve as partners of teachers in education. Parents play a vital role as home facilitators. Their primary role in modular learning is to establish a connection and guide the child. Additionally, Kuruvilla (2020) also asserted that the role of parents in the virtual learning is important. Since students are home-schooled, they have to monitor the development and performance of their child on their day-to-day activities during the independent learning hours.

In modular distance learning, parents play a vital role for their child's learning process at home. They utmost support and guidance for their child is needed in order for them to continue their child's education at home. Shifting to new approach in learning, Quinones (2020) defined distance learning to a learning delivery modality, where learning takes place between the teacher and the learners who are geographically remote from each other during instruction. This is far different from face-to-face learning were in teachers are the one facilitating learning at school. Here, parents exerted more effort and time to make learning happen.

Interview Question 3. How do you teach or guide your child in their module at home?

\section{Table 3}

Annotated exemplars on the varied strategies used as a parent-teacher

\begin{tabular}{lll}
\hline Participant & \multicolumn{1}{c}{ Responses } & \multicolumn{1}{c}{ Observation } \\
\hline Parent 1 & "Ano po ma'am binabasa ko po muna yung mga guide na binibigay sa kanila para & Parent 1 and 7 \\
& alam ko po anong mga ipapagawa sa kanila. Tapos po ma'am ayun po binabasa ko & shared their positive \\
& rin yung mga lesson niya sa kaniya para mas maintindihan niya. Ayun po & outlook when it \\
& hinahayaan ko lang po siya na magsagot tapos kung may tanong po siya ayun po & comes to guiding \\
& sinasagot ko na man po tinutulungan ko po siya.” & their child at home. \\
Parent 7 & "Ano po ma'am ahh binabasa ko po muna yung lesson po tapos ipinapaliwang ko na & Both of them were \\
& po sa kaniya ang lesson para po maintindihan niya. Pinapanood ko rin po siya sa & being honest in \\
& youtube yung mga educational videos para dagdag po. Tapos nagpaprint po ako & sharing and were \\
& yung ano ma'am yung sa DepEd commons mga sample activities po dun para & showing seriousness \\
& dagdag din po ma'am para kahit nasa bahay mo may ginagawa po siya activity. & in their tone. \\
& Ayun lang ma'am nagtititseran po kame dito sa bahay." & \\
\hline
\end{tabular}


When parents were asked on how they teach or guide their child in their module at home and how do they use other learning materials such as videos on the internet, they both shared their experiences in a serious manner. Both of them clearly explained their thoughts on teaching their child at home. Parents shared their own techniques on facilitation learning at home. They explained that since they are still young and in primary level, their assistance is needed. For them one of their techniques in teaching their child in their module is by reading their learning materials first and then explaining to them.

Specifically, Parent 1 made sure that her child is the one answering the module. She seriously mentioned that her child is the one answering the module with her guidance. Meanwhile, for Parent 7, one of her techniques in teaching her child is by utilizing other online educational platforms for extra learning and by also giving her child additional activities from educational platforms as well.

According to Kuruvilla (2020), the role of parents in the virtual learning is important. Since students are home-schooled, they have to monitor the development and performance of their child on their day-to-day activities during the independent learning hours. Without the help of the parents, teachers will not be able to meet the desired learning outcomes at the end of the day.

Based on the testimonies of the parents, they guide their children at home by learning the content of the module and then observe how they follow the instructions in it, and monitor their development. Parents try to explain he lesson to their children, provide them with supplementary learning materials to support learning, like learning video and sample activities. Their role is vital in the continuity of learning of their child that they try to deliver effective learning at home through varied strategies to supply the needs of their child when it comes to learning. Parent's role in remote learning requires time and effort to efficiently deliver quality education at home.

Interview Question 4. How do you manage your time in teaching and guiding your child in their module and being a mother at home?

\section{Table 4}

Annotated exemplars on the dealing with time on modular learning

\begin{tabular}{|c|c|c|}
\hline Participant & Responses & Researcher's Observation \\
\hline Parent 14 & $\begin{array}{l}\text { "Okay halimbawa po marami akong gagawin sa araw na ito, kunwari sa } \\
\text { umaga dun kame gagawa ng mga Gawain tulad ng pagluluto o paglilinis ng } \\
\text { bahay tapos maglalaan ako ng oras kung saan ako maluwag kunwari kahit } \\
\text { siguro sa tanghali o hapon, kung ano yung oras na maluwag kame dun kame } \\
\text { magsasagot." }\end{array}$ & $\begin{array}{l}\text { Parent } 14 \text { shared her thougths } \\
\text { in a serious manner but ended it } \\
\text { with a smile. }\end{array}$ \\
\hline Parent 15 & $\begin{array}{l}\text { "Yung ano naman yung sa paghati sa oras medyo ano talaga teacher medyo } \\
\text { mahirap kasi nagtatrabaho tapos pagdating trabaho ano pa ahh magtuturo ng } \\
\text { module so bali dun pa lang sa oras na yan medyo ano na po ako jan } \\
\text { nahihirapan. So ang ginagawa ko pagdating dito ang ginagawa ko kasi hindi } \\
\text { ko iniisip yung pagod basta sa akin magagawa ko bilang isang tatay bilang } \\
\text { iang solo parent magagawa ko yung trabaho ko dun sa mga anak ko na } \\
\text { ipinangako ko sa kanila na ano na kakayanin namin to kahit na modular. } \\
\text { Bilang kasi magulang pagdating sa bahay ginagawa ko parin naman yung } \\
\text { tungkulin ko bilang isang magulang yung alagaan sila yung ano pang } \\
\text { pwedeng gawin para sa ikabubuti nila gaya po ng pagluluto, naglilinis ganun } \\
\text { po." }\end{array}$ & $\begin{array}{l}\text { Parent } 15 \text { showed frustration } \\
\text { while sharing his feelings. He } \\
\text { looked concerned about the } \\
\text { well-being of his children and } \\
\text { is determined for his children's } \\
\text { future. }\end{array}$ \\
\hline
\end{tabular}

When asked about managing time in modular distance learning, Parent 14 and Parent 15 have their own way in managing their time in being a parent and a facilitator at the same time. Parent 14 expressed her experiences with timeline. She clearly stated about her schedule for cleaning and for module time. Meanwhile, Parent 15 showed frustration when sharing his experiences. Since he is a single father, finding time is challenging for him. He looked concerned when he was sharing because he is thinking about the well-being of his children since he is also working. Overall, he still looked determined when sharing his thoughts on managing time in remote learning. 
Moreover, Carling (2020) mentioned that one way in helping children focus and engage in distance learning, is to adjust their schedule as needed. She explained that if their child is very engaged in learning, they need to make a change in schedule to allow for break and can be completed for a different time. With this, parents can do extra activities at home to maximize their time in facilitating learning with their child.

The experience shared by the parents is a manifestation that their prime concern is the educational well-being of their children. By means of dealing with time, parents learned to balance their time for work, house chores, and their role in home-based learning. Their continuous effort and perseverance showed that they can finish their tasks. Thus, they made time to collaborate with the learning activities of their children and able to spend more time with them.

Interview Question 5. What are the common problems that you encountered while teaching or guiding your child in their module?

\section{Table 5}

Annotated exemplars on subsiding focus on learning

\begin{tabular}{|c|c|c|}
\hline Participant & Responses & Researcher's Observation \\
\hline Parent 6 & $\begin{array}{l}\text { "Para sa akin po, paminsan mahirap ipaliwanag sa kanya yung aralin kasi po } \\
\text { medyo pahirap ng pahirap na po so may mga bagay po talaga na ako mismo } \\
\text { hindi ko alam po so ayun po. Tapos po maiingay rin po ng mga kapatid niya } \\
\text { kaya ayun nawawala po siya sa focus." }\end{array}$ & $\begin{array}{l}\text { Parent } 6 \text { she seems to be } \\
\text { having a difficult time when } \\
\text { sharing. But smiled once in } \\
\text { a while. }\end{array}$ \\
\hline Parent 8 & $\begin{array}{l}\text { "Ahhh yung unang una po na aano po sila parang nawawalan po sila sa pokus } \\
\text { kasi nga po maingay po dito sa amin. Pag nakakakita po sila ng mga bata sa } \\
\text { labas nawawalan po sila ng pokus sa pag aaral. Tapos may mga time po } \\
\text { talaga na tamad na tamad silang gumawa kasi pag lalo na po kapag hirap } \\
\text { kameng hanapin yung isasagot dun sa ano tapos naggoogoogle pa ako } \\
\text { naghahanap pa ako sa internet, siya naman parang tinatamad na siyang gawin } \\
\text { yung ano niya pero tinatapos naman po niya kasi sinasabi po namin } \\
\text { sinasabihan ko po sila na bago sila makapaglaro tapusin po muna nila yung } \\
\text { gawain nila." }\end{array}$ & $\begin{array}{l}\text { Parent } 8 \text { expressed her } \\
\text { frustration on the problems } \\
\text { at home. She was very } \\
\text { detailed and serious in } \\
\text { sharing. }\end{array}$ \\
\hline
\end{tabular}

In terms of the common problems encountered by parents while teaching or guiding their child in their module, both parents shared their own problems in a serious manner. For Parent 6, though seemed to have a difficult time when sharing, she ended it with a smile. She shared her experiences that as time goes by lessons in the module are getting difficult for them to explain to their child at the same time their child experiences difficulty in learning. She also mentioned about the other distractions such as the noise that made her child easily distracted and out of focus. Meanwhile, Parent 8 expressed her frustration on the problems at home in a serious manner as well. She explained that their learning environment is one of the problems she encountered.

In line with this, Garcia (2020) mentioned that one of parents' roles in modular distance learning is to set guidelines and daily routine must be established, since discipline always starts at home parents need to be consistent with their rules at home but in a nice way. In this way, their child can focus on answering in the module. Moreover, Carling (2020) pointed out that parents may reduce distractions at home when their cild become easily distracted. She explained that when their child is doing school work, if possible, they must reduce distractions and provide a designated workspace that is comfortable for their child. Hence, the testimonies of the parents of the common problems they encountered in modular teaching revealed that as the time passed, their children became passive, unconcerned and disgruntled with their study.

Interview Question 6. How did you convince your child to answer the module when there was a time that he/she does not want to answer the module?

When asked about how they convinced their child in answering the module both parents expressed their thoughts with calmness and happiness. For Parent 11, it was clearly shown in her face that she was happy when thinking about the times on what she did to convince her child. For Parent 14, she also looked happy and contented when sharing her thoughts by being positive on the problem. This only showed that parents' role at 
Lopez, J. A.

home learning is broad and they need to be flexible for their child.

Table 6

Annotated exemplars on the forms of encouragement

\begin{tabular}{|c|c|c|}
\hline Participant & Responses & Researcher's Observation \\
\hline Parent 11 & $\begin{array}{l}\text { Ahh minsan talaga ayaw niyang gumawa naglalaro gusto niya maglaro } \\
\text { sometimes pinagbibigyan ko po muna siya na maglaro kahit ilang minutes and } \\
\text { then babalik po kame sa ano sa lesson or minsan ano ano ko pinapromise ko } \\
\text { siya ng treats or ng sige later pwede siyang manood ng po kasi paminsan wala } \\
\text { din po siya sa mood. And minsan pinapromise ko po sa kanya sa mga treats or } \\
\text { sinasabi ko po sige later pwede ka manood ng video kapag natapos niya ganun } \\
\text { na lang usapan. Pero minsan talaga mahirap din talaga syempre nasa bahay } \\
\text { feeling nila sa bahay lang siya, maglalaro lang." }\end{array}$ & $\begin{array}{l}\text { Parent } 11 \text { answered the } \\
\text { question calmly while pausing } \\
\text { once in a while, and looks } \\
\text { happy on how she was able to } \\
\text { convince her child. }\end{array}$ \\
\hline Parent 14 & $\begin{array}{l}\text { "Kapag may araw talagang na ayaw niyang sumagot ayaw niyang gumawa } \\
\text { ang ginagawa ko sa kanya syempre kinakausap ko. Hindi mo naman yan } \\
\text { pwedeng pilitin eh paluin eh kasi lalo yang hindi susunod. Kinakausap ko siya } \\
\text { na oh anak kailangan mo ng gawin yung module mo kasi ipapasa na natin to } \\
\text { inaantay na to ng teacher mo. So pag narinig po niya yun yun na maggagawa } \\
\text { na siya kikilos na siya. Hindi naman siya mahirap pagawain eh babae eh pag } \\
\text { ganun kikilos na siya." }\end{array}$ & $\begin{array}{l}\text { Parent } 14 \text { looked happy and } \\
\text { contented while sharing her } \\
\text { feelings about convincing her } \\
\text { child. }\end{array}$ \\
\hline
\end{tabular}

Modular distance learning has never been easy for parents. With the current situation that they are facing at home, they cannot avoid the times when their child does not want to answer the module. However, parents were able to address these difficulties through different forms of encouragement.

In line with this, Servito (2020) clearly mentioned that of the parents' role is to give appropriate praises, encouragement, and rewards to heighten their child's motivation to learn. By doing this, learning at home can be fun and their child was motivated to learn and answer in the module. In addition, according to Raising.children.net.au website, praise can nurture their child's confidence and sense of self. By using praise, they are showing their child how to think and talk positively about themselves. Parents can help their child learn how to recognize when they do well and feel proud of themselves.

Moreover, Epstein Parent Involvement Model (2019) explained one factor that parenting is helping families build supportive home environments for children as students. Some practice examples of this type are suggestions for home conditions that serve to improve learning, parental education activities and family support programs. Additional to parents' roles, they may think of different forms of encouragement suitable for the child. When their child has no interest in doing the module, they may talk to their child to know their feelings or concerns. Parents are encouraged to be aware of their child's mood when answering the module because this may impact the child's learning process. Parents shared the same testimonies to encourage their child in answering the module.

Interview Question 7. What are the challenges or concerns you encountered in modular distance learning?

Table 7

Annotated Exemplars on the Challenges on Modular Distance Learning

\begin{tabular}{|c|c|c|}
\hline Participant & Responses & Researcher's Observation \\
\hline Parent 8 & $\begin{array}{l}\text { "Hamon po para sa akin po yung oras po at mga gawain sa } \\
\text { bahay kasi may baby po ako tapos kailangan ko pa po } \\
\text { siyang asikasuhin sa module niya, kaya adjust lang po } \\
\text { talaga." }\end{array}$ & $\begin{array}{l}\text { Parent } 8 \text { answered the } \\
\text { question with concerned } \\
\text { look on her face, she was } \\
\text { also thinking deeply on } \\
\text { sharing her experience. }\end{array}$ \\
\hline Parent 13 & $\begin{array}{l}\text { "Alalahanin ko po syempre bilang magulang parang hindi } \\
\text { sapat yung naituturo naming na katulad ng pagtuturo ng } \\
\text { isang guro." }\end{array}$ & $\begin{array}{l}\text { Parent } 13 \text { was serious while } \\
\text { answering the question and } \\
\text { clearly showed the } \\
\text { frustrations on her face. }\end{array}$ \\
\hline
\end{tabular}


When asked about the challenges or concerns they encountered in modular distance learning, both parents were serious when sharing their experiences. Parent 8 answered the question with concerned look on her face while pausing when she tried to think deeply. Meanwhile, Parent 13 was also serious when answering the question and showed frustrations while sharing her experiences.

In line with this, Abuhammad (2020) stated on his research entitled "Barriers to Distance Learning during the COVID-19 Outbreak: A Qualitative Review from Parents' Perspective" that the parents seemed to have many personal barriers that they felt affected the standard and quality of their children's distance learning experience. It was clear that the parents' own lack of training in how to handle distance learning techniques and materials and the absence of trained personnel who could assist them were key concerns. Finally, the parents raised this issue of their own qualifications. Parents with lower levels of education felt that they were not able to assist their children in studying specific subjects and in handling the necessary technology.

Interview Question 8: How do you cope with these challenges or concerns you encountered in teaching or guiding your child at home?

\section{Table 8}

Annotated Exemplars on the Acceptance and Positive Outlook

\begin{tabular}{ll}
\hline Participant & \multicolumn{1}{c}{ Responses } \\
\hline Parent 1 & "Nakatulong po sa akin ma'am ayun lang po ginawa ko pinaglaanan po Parent 1 and 3 were both \\
& talaga ng time yung aking mga gagawin kasi mahirap po kasi pag hindi ko expressed positive facial \\
& nasunod yung time na yun mas marami po kasi akong gagawin kinabukasan. expression emphasizing how \\
& Tapos po tanong na lang po sa teacher yung mga hindi ko po alam ayun po. they cope such challenges. \\
& Then pray na rin po sa gabi bago matulog para makayanan po naming sa \\
& buhay." \\
& "Ginagawa ko po araw-araw po talaga kami sumasagot sa modyul para \\
& hindi po kame matambakan ng aralin. So ginagawa ko na lang po mag \\
& adjust talaga ng oras at panahon para makayanan po. Diskarte na lang po \\
& ng mommy."
\end{tabular}

When asked about overcoming challenges with in guiding their child at home, both parents expressed positive facial expression. This only showed that they were able to overcome such challenges that they encountered in the delivery of modular approach. Parent 1 emphasized that one way to overcoming such challenges is time allocation, effort and asking for teachers help. For her these helped her allot when she experienced it firsthand. For Parent 3, she also allocated time and effort for guiding her child in the module. Time for parents is really important for them to provide the needs of their children in learning. Clearly, parents become flexible when it comes to their child's benefit.

The testimonies of parents showed that in spite of the challenges they encountered in modular distance learning, the parents are still optimistic in taking their role in the education of their children. Bendijo (2020) asserted that parents are open to adjusting with the new normal setup, their concerns are valid, but parents have nothing to worry about because the teachers will still be facilitating the students' learning by being the ever-ready learning consultants. In addition, ACS International School article stated that, parents' task is to help children climb their own mountains, as high as possible. No one can do more. Whereas, Garcia (2020) affirmed that parents should pray, you need to pray together especially in this time. Moreover, Dado (2020) mentioned that in this time, teachers may need to home visit the learners for remediation or assistance. They can reach them via email, telephone, text message or instant messaging, if it is workable. These alternatives in communication with learners are appropriate in distance learning.

Interview Question 9. What factors or strategies have been helpful for you in teaching your child in this new normal set up despite the challenges you've encountered? 
Lopez, J. A.

Table 9

Annotated Exemplars on Factors to Consider in Dealing with New Normal Education

\begin{tabular}{|c|c|c|}
\hline Participant & Responses & Researcher's Observation \\
\hline Parent 4 & $\begin{array}{l}\text { "Malaking tulong yung working plan na pinapadala sa aming mga } \\
\text { parents. Nasusundan talaga yung mga anong dapat gawin. Kung ano } \\
\text { ano yung pagkakasunod na ahh gawain. Kung paminsan hindi naming } \\
\text { maintindihan yung instructions kinocontact talaga namin yung teacher } \\
\text { niya." }\end{array}$ & $\begin{array}{l}\text { Parent } 4 \text { and } 6 \text { both shared and } \\
\text { expressed their answers in a } \\
\text { comfortable manner and proudly. }\end{array}$ \\
\hline Parent 6 & $\begin{array}{l}\text { "Sa tingin ko po yung paggawa po talaga ng schedule po mga dapat na } \\
\text { ginagawa ko po sa araw-araw. May oras sa pagmomodyul at meron din } \\
\text { po sa bahay." }\end{array}$ & \\
\hline
\end{tabular}

On the factors or strategies that have been helpful for parents in teaching their child in this new normal set up despite the challenges they encountered, both parents proudly shared their thoughts and with positive facial expression. For Parent 4, what helped her most is the weekly home learning plan provided for them by the teachers. For them with this, she was able to teach her child at home in an organize manner and there were able to finish the learning task on time. For parent 6 is having a schedule for her daily tasks. It is important for her to schedule her tasks so that she was able to maximize her time and help her child answering the module.

Particularly, one of the roles of parents mentioned above, was to prepare reading the guide given to them. Based on the article posted in flipscience.ph entitled "Supercharging Filipino Parents is Key for Successful Modular Distance Learning" where Dr. Servito stated that one of their roles is to habitually check the child's workweek plan and ensure that the student sticks to the schedule. Moreover, Garcia (2020), as cited in webinar through Vibal TV, stated that one of parents' roles is to set guidelines and daily routine. This must be established at home. Discipline always starts at home we need to be consistent with our rules at home but in a nice way you can post on the walls their schedules.

Accordingly, Epstein (2019) added that this factor is about providing information and ideas to families about how to help their children at home with their learning. Particularly, this factor involves information on homework policies and how to supervise children, family reading activities at school.

Interview Question 10. How does the transition to new normal education with modular distance learning modality affect you on your daily routine?

\section{Table 10}

Annotated exemplars on the additional responsibilities

\begin{tabular}{cll}
\hline \multicolumn{1}{c}{ Participant } & \multicolumn{1}{c}{ Responses } & \multicolumn{1}{c}{ Researcher's Observation } \\
\hline Parent 5 & "Malaking epekto po nito sa akin as working nga po kame & Parent 5 expressed her answer in a serious \\
& mag-asawa. Oras at panahon namin na ibinibigay sa & manner. But end it with a smile. \\
& kanila. Yung mga gawain isinisingit ko na lang din po sa & \\
& mga gawain sa bahay sa work at sa pagtuturo sa kanila sa & \\
& kaniyang module." & \\
& "Oo naaapketuhan yung oras ko sa trabaho ko kung baga & Parent 10 also expressed her thoughts \\
& sa hanapbuhay naming naapektuhan yun pero dun sa & seriously at first but at the end she showed \\
part na para sa modyul happy ako dun kasi mas & happiness when explaining why she was \\
& nakakabonding ko siya na kung baga yun yung dapat sa & happy. \\
& pag-aaral. Ayun good side at bad side. Happy kasi & \\
& nagkabonding kame bad side kasi meron nabawasan na & \\
& dapat kikitain naming sa family." & \\
&
\end{tabular}

When asked about how the transition to modular distance learning modality, both of them answered in a serious manner. For Parent 5, she was affected by it because of conflict with work since both of them are working - finding time for modular affected them. For Parent 10, she realized that her work was affected in this situation, but in the end, she expressed her positive feeling about this modular distance learning. She explained this situation gave her more time to spend with her child. 
Based on the testimonies shared by the parents, transitioning to new normal education with modular distance learning modality seriously affects their time routine. The Department of Education knows that some parents are occupied just to earn a living, which makes it hard for them to guide their children at home. But the department itself desires the parents to understand that education has to continue for it is their right, and it will be in a way that health and safety will not be compromised. Bayocot (2020) mentioned, "We have to accept the new normal by addressing the challenges of this new normal."

Parental involvement in children's education is a crucial factor for the child's continuing educational development and success in school. Parents' role is vital in the development of their child. The molding of the character of the child starts at home. Every member of the family should strive to make the home a wholesome and harmonious place as its atmosphere and conditions will greatly influence the child's development.

Corollary Question 2. What themes emerged from the testimonies of primary learners' parents from the District of Calamba?

The tables that follow provide the themes that emerged from the different responses of the primary learners' parents in modular distance learning with regard to their role for their children's education.

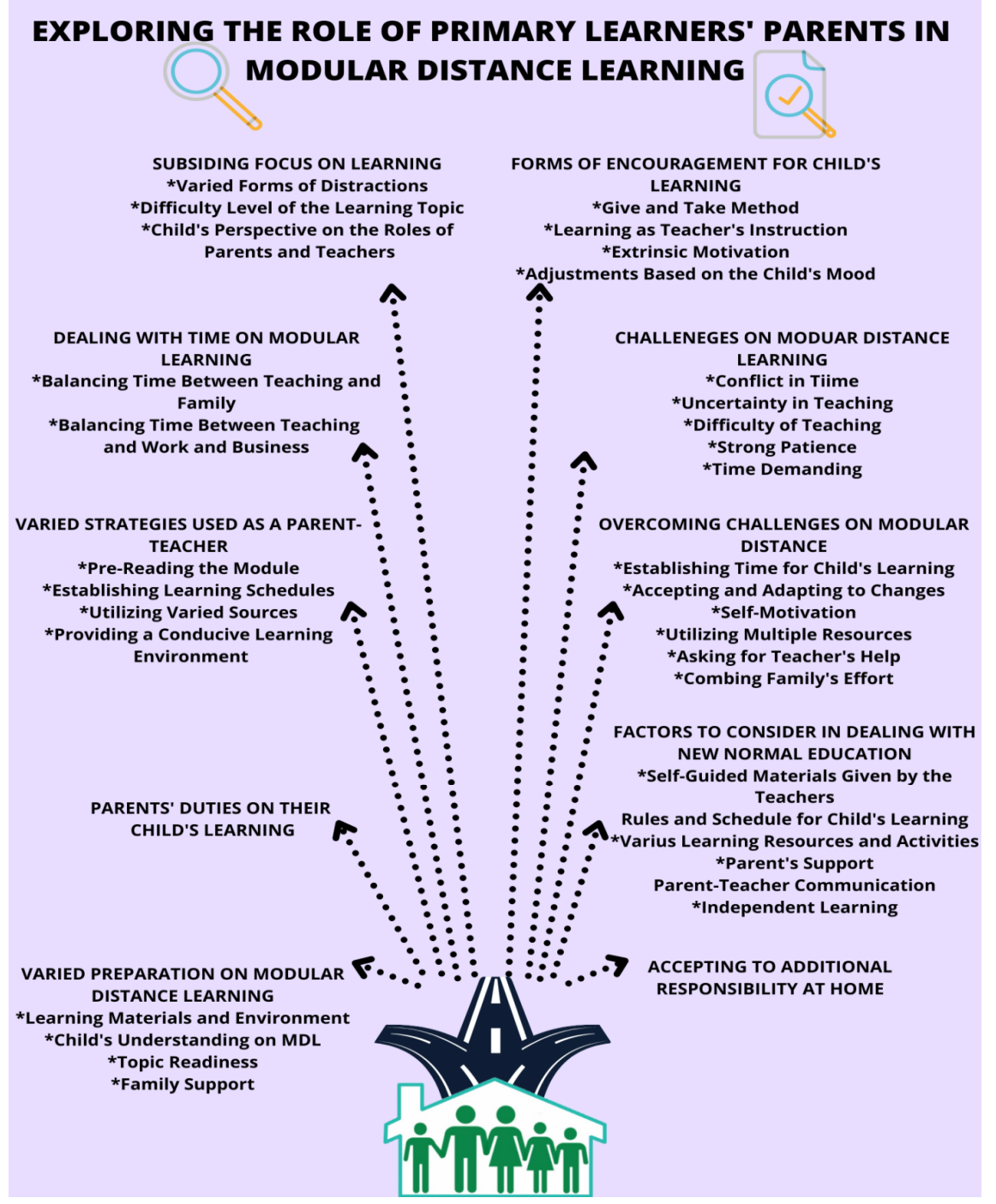


Education has not been easy for the learners, parents, teachers and other stakeholders this school year of 2020-2021 due to pandemic. Different modalities have been offered to learners and parents. This modular distance learning has been a roller coaster ride for the 15 primary learners' parents. For them, being prepared, knowing their roles, using of strategies, and accepting to new normal education are their strengths in overcoming different challenges like limited time and distractions in learning. With their busy schedules due to work and house chores, they made sure that their child will not be left behind in terms of learning. Their effort, perseverance, and unending support made the modular distance learning possible for every learner in this school year.

Corollary Question 3. Based on the findings of the study, what booklet can be proposed to enhance and strengthen the support to parents in teaching and guiding their child at home using module?

Based on the findings of the researcher, the parents' lived experiences in this modular distance learning bring different challenges that they are facing right now. The researcher made a booklet that serve as a guide for parents with regard with their role on modular distance learning. The booklet includes ways to overcome difficulties that they encountered on modular approach in learning. Based on the interviews, the primary learners' parents have different ways in fulfilling their roles for their child's education under the modular learning. Further, this is to remind primary learners' parents the importance of their role and how they can also help their child to succeed in the future.

\section{Conclusion}

\subsection{Consolidated Findings and Reflections}

This phenomenological study delved into the lived experiences of primary learners' parents in modular distance learning. The semi-structured interview with the participants is focused on their experiences with regard to their on their primary learners' child from Grade 1 to Grade 3 on modular distance learning. Parents play a vital role in adapting to new normal with modular distance learning as an approach. Due to a sudden change, parents revealed their stories, challenges, and adapting to this situation. Parents shared various experiences that lead to similar and diverse factors and themes. The significance of acknowledging these findings is to understand the experiences and challenges encountered by primary learners' parents on modular distance learning. This is for them to have clear view on their role as a parent to their child. Based on the findings, primary learners' parents showed different encounters and ways on handling such encounters to fulfill their role on modular distance learning.

The following are the consolidated findings based on the interviews with the participants and emerging themes that arise from the phenomenological inquiry on the testimonies of primary learners' parents from Grade 1 to Grade 3 on modular distance learning. The following are the 10 emerging themes from the semi-structured interviews conducted with parents as teachers for modular distance learning in the new normal: Varied Preparations on Modular Distance Learning; Learning Facilitators; Varied Strategies Used as a Parent-Teacher; Time Management; Subsiding Focus on Learning; Forms of Encouragement for Child's Learning; Challenges on Modular Distance Learning; Factors to Consider in Dealing with New Normal Education; and Accepting to Additional Responsibility at Home.

In distance learning approach, parents play an active role in the learning process of their child. Parents are their first teachers and they have a key role in shaping up their character. Their involvement and encouragement play a crucial role in the success of their child. Moreover, parents have varied preparations on modular distance learning. They showed that for the home-based education of their children through modular distance learning, they found it necessary to prepare a physical learning environment at home. This preparation allowed their child to focus on learning on the module and make them feel safe as well. In the addition, parents revealed that one of their roles is to facilitate learning at home. It is clear from the testimonies of parents that they are very much

48 Consortia Academia Publishing (A partner of Network of Professional Researchers and Educators) 
aware of their main role to their child's education in modular distance learning, and that is to facilitate learning which includes guiding their children to understand clearly the self-guided instructions in the module. Their roles are to facilitate and to guide their child throughout the journey in modular approach, and to fulfill their child's needs in acquiring knowledge and experiences regardless of the situation.

Aside from that, they are not just to facilitate the learning process of their child; they also used strategies as a parent-teacher at home. They also read the content of the module and then observe how their children follow the instructions. Parents also provide and facility supplementary learning materials to support learning, like learning video and sample activities. In modular distance learning, primary learners' parents learned to balance their time for work, house chores, and their role in home-based learning. Thus, they made time to collaborate with the learning activities of their children and able to spend more time with them. For them balancing their time was hard but at the same time they cannot sacrifice the learning of the child. However, their role as parent was not easy for them, there also encountered distractions in home-based learning. Testimonies of the parents of the common problems they encountered in modular teaching revealed that as the time passed, their children became passive, unconcerned and disgruntled with their study. Their children started to become confuse of what is happening around them.

Also, their role on modular distance learning expanded to encountered problems such as not all the time their child wants to answer the module. So as a parent, they thought of ways of the problem. Parents are giving them enough time to play or space for diversion. This was also their means of motivating their child, to give them time to recharge and regain their interest in learning. In addition, parents also encountered common problems on modular teaching, the testimonies of the parents revealed that their primary concern is the challenge of unfamiliarity with the content of the modules which eventually made their child passive learners. Furthermore, parents' role revealed to think of factors that helped them cope with the challenges posed by modular distance learning. They revealed that establishing time and accepting to change in education helped them to fulfill their roles on their child's learning.

Lastly, the transition to new normal education with modular distance learning modality seriously affects their time routine. The Department of Education knows that some parents are occupied just to earn a living, which makes it hard for them to guide their children at home. In time, they were able to adjust to the new normal set up. Their role in the distance learning had not been easy because of conflicts and additional responsibilities. Hence, for the sake of their child's learning, they were able to cope with the challenges brought by the pandemic in education.

During the interview, the researcher learned that parents have been so much prepared and even excited in the implementation of modular distance learning as they converted a part in the home into learning area, a mini-classroom perhaps, where their children feel the atmosphere of the school even at home. However, the parents also show awareness that their children also need to be prepared not just mentally but also emotionally. They oriented them on the process of home-based learning through modular distance learning that in the absence of their teacher, they, as parents will be their instructor or tutor. Parents have been helpful for their child child's education in modular distance learning. The parents willingly guided their children at home by learning the content of the module and then observe how they follow the instructions in it, and monitor their development. They try to explain he lesson to their children, provide them with supplementary learning materials to support learning. These all are testimonies that their prime concern is the educational well-being of their children. By means of time management and perseverance, Parents learned to balance their time for work, house chores, and their role in home-based learning. Thus, they made time to collaborate with the learning activities of their children and able to spend more time with them.

Modular distance learning brings challenges to all primary learners' parents but for them it is just a challenge or problem. Also, they believed that there is always a way in coping with these. For the continuity of learning amid the pandemic, parents sacrificed so much time and effort for their child. Collaboration and 
communication of parents and teachers are needed for this modular distance learning to be successful. Parent involvement in times of pandemic helped in the transition on modular distance learning.

\subsection{Recommendations}

Based on the consolidated findings and reflections of this qualitative study, the following are the recommendations offered:

1. Parents should focus on their roles for their child's learning process on modular distance learning. They have to focus on their effort and parenting for the continuous learning that may help their child succeed on every task.

2. The teacher adviser should immediately respond to the inquiry of the parents, therefore, the utilization of all communication media will be needed to keep all channels of communication open between them and the parents. They should provide parents with strategies or techniques in guiding the primary learners at home.

3. Master Teachers should help and support primary learners' teachers to make useful booklets for the tips and strategies in guiding learning at home.

4. School Heads should support and encourage teachers by sending them and providing them with different trainings and webinars in upskilling them. They may help teachers to update their knowledge and skills for them to be able to share with the primary learners' parents.

5. The utilization of booklet produced by the researcher should be a guide for the parents to refresh them with strategies and techniques in modular distance learning approach.

6. Future researchers may conduct similar research which can come up with correlational type of research which relates to the problem that was tackled by the researcher.

\section{References}

Abuhammad, S. (2020). Barriers to distance learning during theCOVID-19 outbreak: A qualitative review from parents' perspective. Heliyon, 6(11), 5482. https://doi.org/10.1016/j.heliyon.2020.e05482

Ancheta, R. (2020). The new normal in education: A challenge to the private basic education institutions in the Philippines? International Journal of Educational Management and Development Studies, 1(1). https://doi.org/10.53378/345960

Article in RaisingChildren.Net.Au. (2021). Praise, encouragement and rewards. Retrieved from https://raisingchildren.net.au/toddlers/connecting-communicating/connecting/praise

Balani, M. (2020). Encouraging curiosity in children: Here's what to know. Retrieved from https://www.today.com/parenting-guides/encouraging-curiosity-early-childhood-t179019

Basilaia, G., \& Kvavadze, D. (2020). Transition to online education in schools during a SARS-Cov-2 Coronavirus (COVID-19) Pandemic in Georgia. Pedagogical Research, 5(4). https://doi.org/10.29333/pr/7937

Bendijo, A. A. C. (2020). New normal: How parents embrace the challenges in education. Retrieved from https://www.depedmalaybalay.net/articles/new-normal-how-parents-embrace-the-challenges-in-educatio $\underline{\text { n.html }}$

Ben-Joseph, E. P., \& Pendley, J. S. (2020). Coronavirus (COVID-19): How to talk to your child. Retrieved from https://kidshealth.org/en/parents/coronavirus-how-talk-child.html

Bhamani, M., Bharuchi, A., \& Kaleem A. (2020). Home learning in times of COVID: Experiences of parents. Journal of Education and Educational Development, 7(1). https://doi.org/10.22555/joeed.v7i1.3260

Cahapay, M. (2020). Rethinking education in the new normal post-COVID-19 era: A curriculum studies perspective. Aquademia, 4(2), 20018. https://doi.org/10.29333/aquademia/8315

Canonizado, I. C. (2020). The significant role of parents as the learning facilitators to their children in the new

50 Consortia Academia Publishing (A partner of Network of Professional Researchers and Educators) 
Exploring the role of primary learners' parents in modular distance learning

normal education. Retrieved from

https://discover.hubpages.com/education/The-Significant-Role-of-Parents-as-the-Learning-Facilitators-t o-their-Children-in-the-New-Normal-in-Education

Carling, L. (2021). 8 Tips to help your child focus and stay engaged during distance learning. Retrieved from https://education.jhu.edu/2020/04/8tipsforfocus/

Casiple, R. (2020). Modular instruction. Retrieved from https://dailyguardian.com.ph/modular- instruction/

Dado, N. L. (2020). Challenges parents face in education's new normal. Retrieved from https://www.manilatimes.net/2020/08/09/business/sunday-business-i-t/challenges-parents-face-in-educa tions-new-normal/752688/

Dangle, Y. R. P., \& Sumaoang, J. D. (2020). The implementation of modular in the Philippines secondary public schools distance learning. Proceedings of the 3rd International Conference on Academic Research in Science, Technology and Engineering. https://www.dpublication.com/abstract-of-3rd-icate/27-427/

Dayo, I. J. (2020). DepEd cites parents' role in educating under the new normal. DepEd.

Department of Education. (2020). Adoption of the basic education learning continuity plan for school year 2020-2021 in light of the COVID-19 public health emergency. Retrieved from https://www.deped.gov.ph/wp-content/uploads/2020/06/DO_s2020_012.pdf

Department of Education. (2020). Briones welcomes 24.7M learners for SY 2020-2021, declares opening of classes a victory. Retrieved from https://www.deped.gov.ph/2020/10/06/briones-welcomes-24-7m-learners-for-sy-2020-2021-declares-op ening-of-classes-a-victory/

FlipScience. (2020). Supercharging Filipino parents is key for successful modular distance learning. Retrieved from https://www.flipscience.ph/news/features-news/tagapagdaloy- modular-distance-learning/

Hamidun. (2019). Parent involvement in children learning to academic excellence. Retrieved from https://www.series.gci.or.id/assets/papers/icosh2-2019-83.pdf

Hussain, M. (2019). Parental involvement and students' educational achievement: A phenomenological study. International Journal of Scientific \& Engineering Research, 10(2), 1073-1080.

Keith, K. L. (2020). How parents can become more involved in schools. Retrieved from https://www.verywellfamily.com/parent-involvement-in-schools-619348\#citation-1

Llego, M. A. (2020). DepEd learning delivery modalities for school year 2020-2021. Retrieved from https://www.teacherph.com/deped-learning-delivery-modalities/

Lucie, R. (2017). Bookwidgets page entitle using reward system to motivate students. Retrieved from https://www.bookwidgets.com/blog/2017/01/using-reward-systems-to-motivate-students

Luz, J. M. (2020). How ready are our basic education schools for the 2020 school opening? Retrieved from https://www.rappler.com/voices/thought-leaders/analysis-how-ready-basic-education-schools-for-2020opening

Magsambol, B. (2020). 8.8 million parents prefer modular distance learning for students. Retrieved from https://www.rappler.com/nation/deped-says-parents-prefer-modular-learning-students

Malipot, M. (2020). Role of parents in the 'new normal' in education crucial - DepEd. Retrieved from https://mb.com.ph/2020/04/30/role-of-parents-in-the-new-normal-in-education- crucial-deped/

Mauro, T. (2020). Understanding the paraprofessional's role in schools. Retrieved from https://www.verywellfamily.com/what-is-a-paraprofessional3106873\#citation-2

McLeod, S. (n.d.). The interview research method. Simply psychology. Retrieved from https://www.simplypsychology.org/interviews.html

Mean-chin. (2020). Student's new normal: Modular distance learning. Retrieved from https://www.uniquephilippines.com/students-new-normal-modular-distance-learning/

MGSD. (2020). DepEd stresses role of parents in educating children under 'new normal'. Retrieved from https://mindanaogoldstardaily.com/deped-stresses-role-of-parents-in-educating-children-under-new-nor $\underline{\mathrm{mal} /}$

Obana, J. (2020). What will schools look like under the 'new normal'? Retrieved from https://www.grantthornton.com.ph/insights/articles-and-updates1/from-where-we-sit/what-will-schools- 
look-like-under-the-new-normal/

Pacheco, J. (2020). The "new normal” in education. https://doi.org/10.1007/s11125-020-09521-x

Pelayo. (2020). DepEd eyes hiring para-teachers to aid parents in 'new normal' classes. Retrieved from https://www.untvweb.com/news/deped-eyes-hiring-para-teachers-to-aid-parents-in-new-normal-classes/

Quinones, M. (2020). DepEd clarifies blended, distance learning modalities for SY 2020-2021. Retrieved from https://pia.gov.ph/news/articles/1046619

Regional Order. (2021). Guidelines on curriculum implementation in the new normal. Retrieved from https://depedcalabarzon.ph/wp-content/uploads/2021/03/RO-NO-4-S.-2021.pdf

Saxena, R., \& Saxena S. K. (2020). Preparing children for pandemics. In S. Saxena (Ed.), Coronavirus Disease 2019 (COVID-19). Medical Virology: From pathogenesis to disease control (pp. 187-198). Springer, Singapore. https://doi.org/10.1007/978-981-15-4814-7_15

Toquero, C. M. (2020). Challenges and opportunities for higher education amid the COVID-19 Pandemic: The Philippine Context. Pedagogical Research, 5(4). https://doi.org/10.29333/pr/7947 